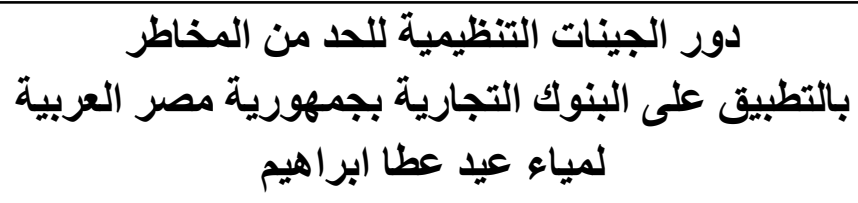

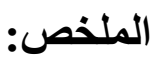

وبالر غم من التطور الهائل الذي شهده العالم في الآونـة الأخيرة إلا انهـ ظهر

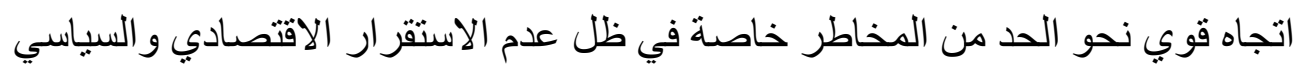

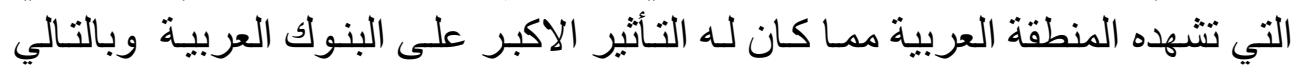
العالمية .

و تقوم هذه الدر اسة علي در اسة الخصـائص التنظيمية للمنظمـة التي تؤثر في

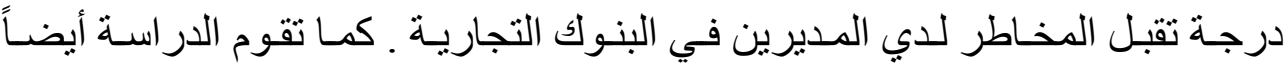

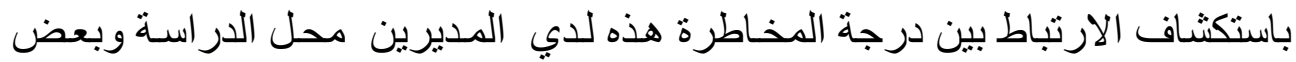

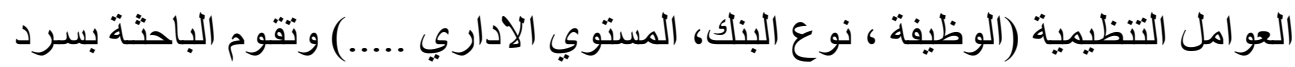

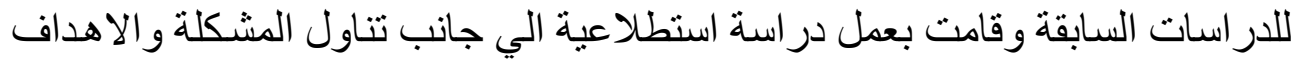

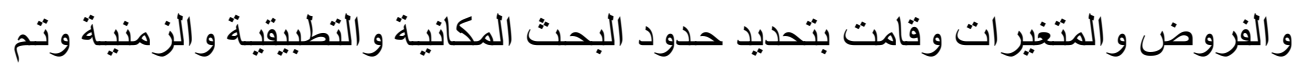

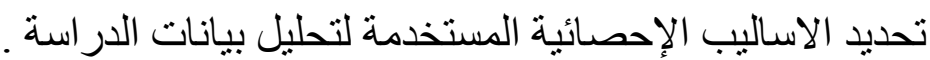

\title{
Abstract:
}

Despite the recent development in the world, there has been a strong trend towards risk reduction, especially in light of the economic and political instability in the Arab region, which has had the greatest impact on Arab and global banks.

This study examines the organizational characteristics of the organization that affect the degree of risk acceptance of managers in commercial banks. The study also explores the correlation between this degree of risk for the principals under study and some organizational factors (function, type of bank, level of management ...) The researcher narrated the previous studies and carried out a survey study in addition to addressing the problem, objectives, hypotheses and variables and defined the 


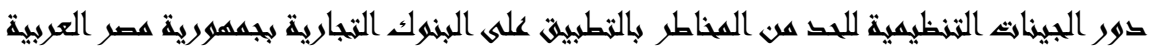
لمياء عيد عطا ابراهميه

limits of spatial and applied research and time was determined statistical methods used to analyze the study data.

\section{اولاً :المقدمة}

نظر اً لما يثههده العالم من تقدم في العلوم الادارية وخاصـة في مجال المنظمات

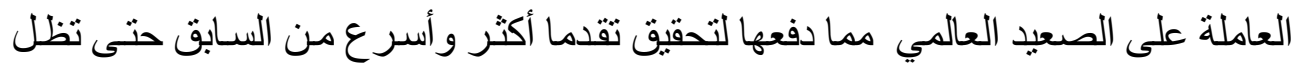

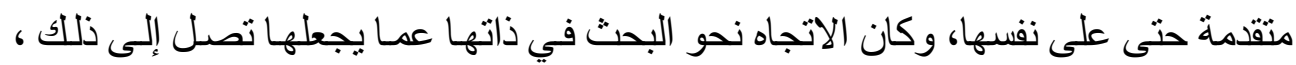

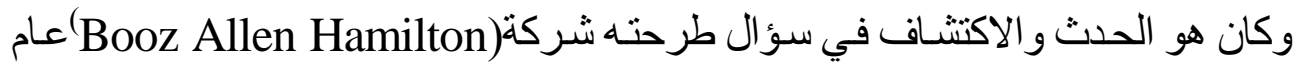

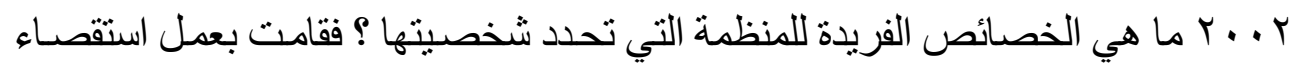

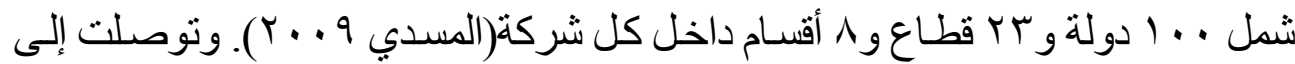
أن لكل منظمة خصائصها الفريدة التي تجعلها مختلفة عن بقية المنظمات حتى التي لتي تعمل

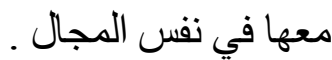

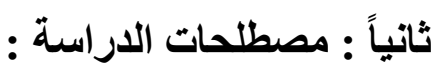

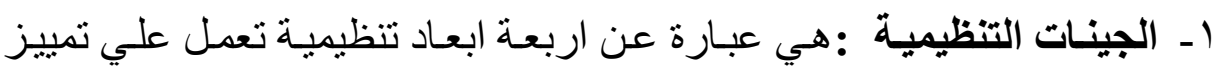

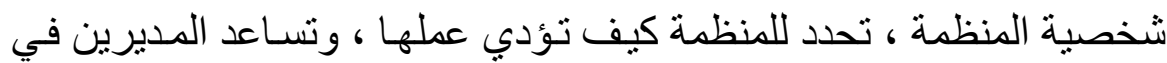

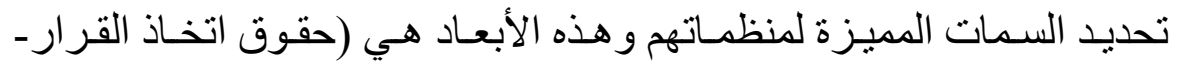

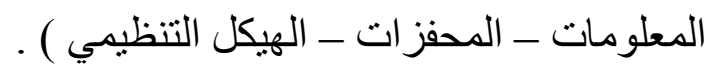

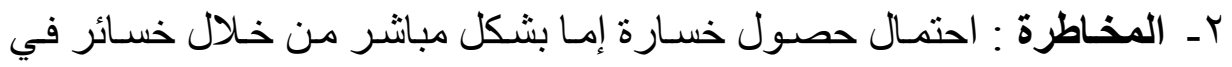

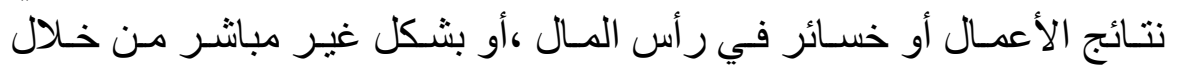
وجود قيود تحد من قدرة البنك على تحقيق أهدافه و وغاياته .

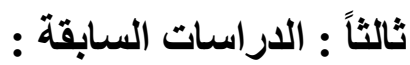

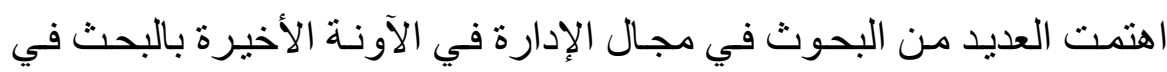

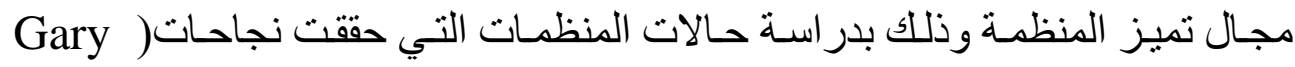

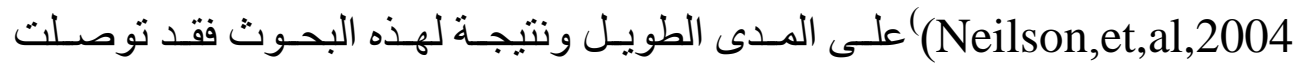

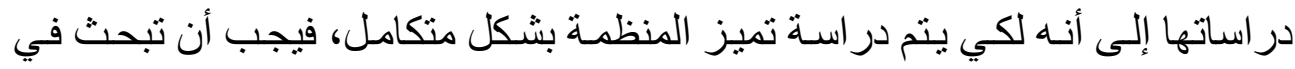

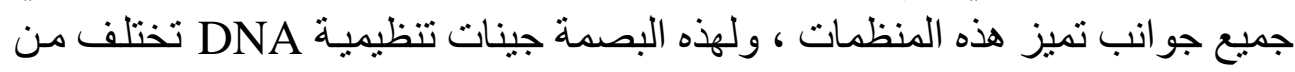

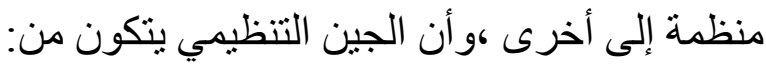

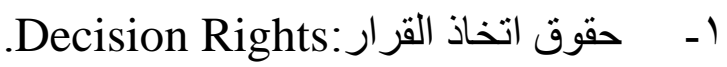




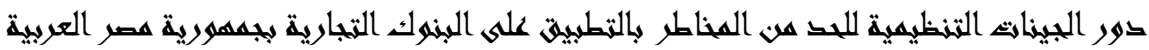
لمياء عيد عطا ابراهميه

و هي عبـارة عن تحديــ التقتيـات الأساسـية الخاصـة بكيفيـة اتخـاذ القرار ات فعليـا

$$
\text { بالمنظمات. }
$$

.Information : ب المعلومات

و هـي الوسـيلة الأسـاسـية لنشـر ونقـل المعرفة داخـل المنظمـة مسن الأفر اد الذين

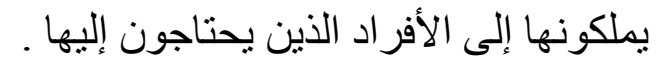

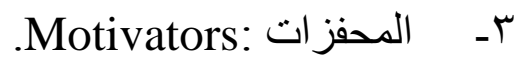

و هي تلك الوسائل التي تستخدمها المنظمة لحث العاملين ودفعهم لأداء أفضل .

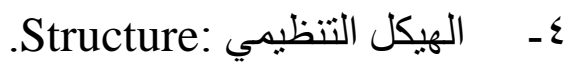

و يعبر التهيكل التتظيمي عن الخريطة التتظيميـة للمنظمـة والتي تحتوى على المسـتويات الإداريـة والتقـارير المباشـرة والمسـار الـوظيفي وحركـة التـقنلات

$$
\text { والترقيات . }
$$

وحيث أن هذه الار اسة تثناول قياس أثز الجينات التتظيمية DNA على ميل المديرين للمخاطرة ،فإنه يمكن تقسيم الدراسـات السسابقة المرتبطة بمحور الفكرة التي تدور حوله هذا الموضوع إلى ثلاث مجموعاث أساسبة يمكن ثوضيح كل منها فيما يلي : ا - الدر اسات التي تتاولت الجينات التتظيمية r - الدر اسات التي المخاطرة . ا - الدر اسات المتعلقة بالجينات التتظبمبة : هناك عدد قلبـل مـن الدر اسـات التي تتاولت الجينـات التتظيميـة ، نظر ا لحداثة هذا المفهوم سـو اء على مستوى الدر اسـات الأجنبيـة و العربيـة بـل تتـدر الدر اسـات العربيـة بالمكتبة العربية في هذا المجال و عدد قليل بالمكتبة الأجنبية ،وسوف تتناول الباحثة ما أُتيح لها من هذه الدراسات على النحو التالي:

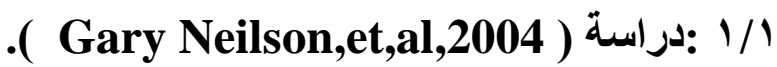

قام الباحثون بعمل دراسة على أهم السمات الأصيلة التي تـؤثر على خصـائص الثركة وتؤثر على سلوك الأفر اد كوكيف يؤثر السـلوك الجمـاعي على أداء الثـركة

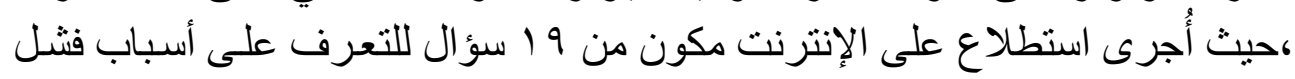

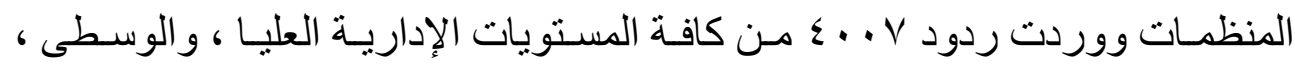
و الإثـر افية ، و المـوظفين ومـن كافـة الوظـائف بالمنظمـة مـن تسـويق و إنتـاج وتمويـل و أفر اد ،ومن كل أنو اع المنظمات من بثرول وصحة وبنوك و إدارة ،وكانت النتيجة أن 


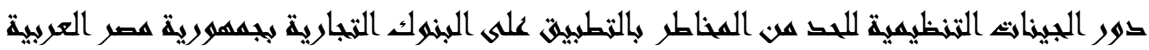
لمياء عيد عطا ابراهميه

هنالك سنة ملاحظات حول انتشار الخلل بين منظمات الأعمال:

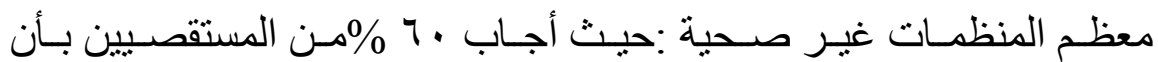

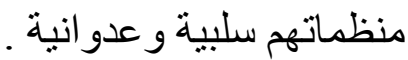

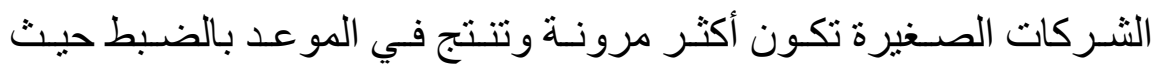

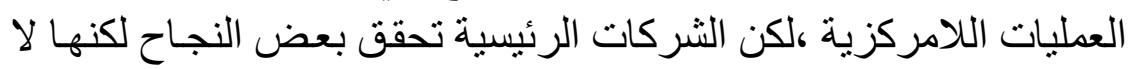
تخلو من بعض الخلل. المو اقف تتحدد في أعلى : Altitude determines attitude أي أن كل شيء بيد الإدارة العليا . العيد وانتهت الدر اسـة إلى أن المنظمـات تستطيع تغيير الجينـات التنظيميـة، لها

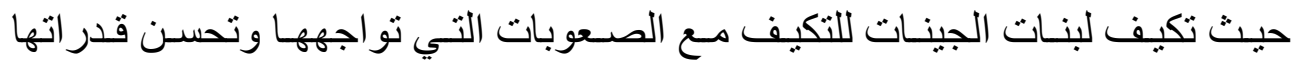
التنفيذية.

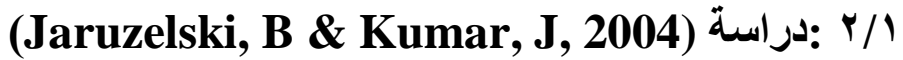

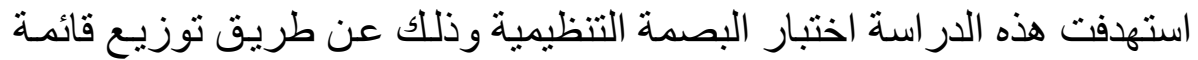

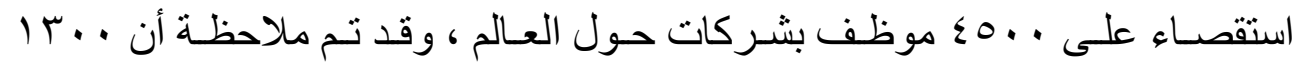

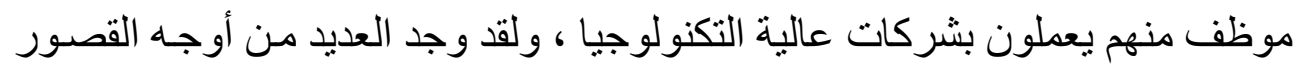

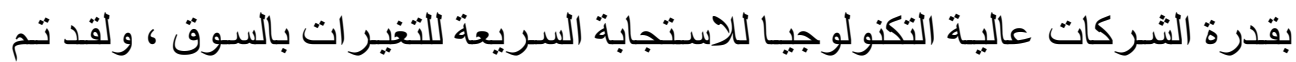
التوصل إلى النتائج التالية : - عدم قدرة العديد من الثركات على التكيف السريع مـع التغير بالتكنولوجيـا

$$
\text { و السوق }
$$

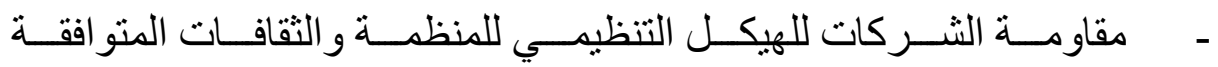

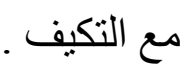

العديـد مـن الشـركات لـم تنشـــئ العمليـات الإداريــة الضـرورية لتحقيـق

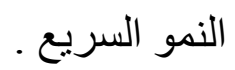

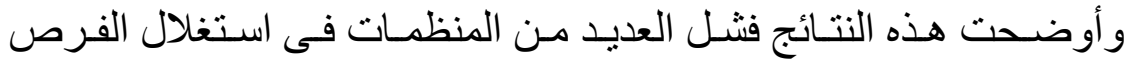

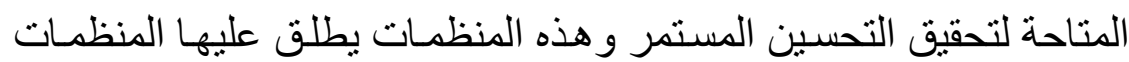

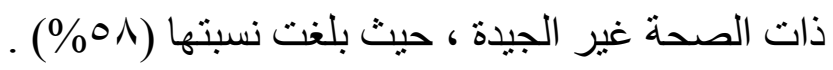

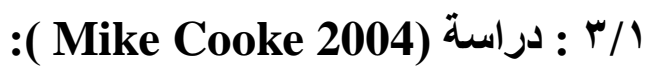

أجريت هذه الدراسة لمعرفة أثر الجينات التتظيمية على نمو المنظمة ،فتتاولت 


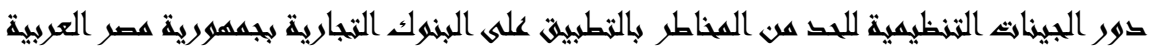
لمياء عيد عطا ابراهميه

الدراسة عدد (ع شركة) من العاملة في مجال السلع الاستهلاكية ، للتعرف على العوامل التي تؤثر على استراتيجية النمو بهذه الثركات فكانت النتيجة أنه لم تعد العلامة وقنوات التوزيع وحدها هي التي تؤثز على خلق القيمة بل إن هناك عو امل أخرى كتخصيص قيمة الخدمة التي تقدم لقوات التوزيع و العملاء كو إدارة فعالية تخصيص الموارد وكانت الأبعاد الأساسية لقياس نمو المنظمة هي (رؤية المنظمة الثاملة للنمو - الدعم الكامل من الإدارة العليا- و أوليات و اضحة وفعالة لتدبير المواردـ-

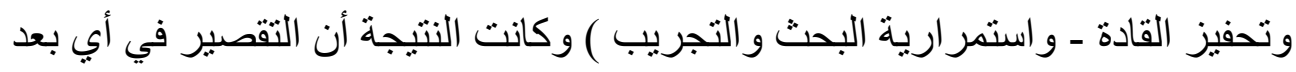
من هذه الأبعاد يهدد قدرة المنظمة على تحقيق النجاح وخاصة المنظمات التي تعمل في مجال السلع الاستهلاكية ، كانت النتيجة أن هناك علاقة بين تحقيق معدلات نمو مرتفعة ، و الجينات التنظيمبة ، organization DND متمثلة في: - مواءمة الهيكل التنظيمي لتحقيق النمو عن طريق تخفيض عدد المستويات التنظيمية وخلق فرص صو وظيفية مجزية. - القيادة وسر عة اتخاذ القرار ، عن طريق تفويض مزيد من الصلاحيات للعاملين -بناء وظيفة لنشر المعلومات بين الوظائف المشتركة عبر الحدود التنظيمية لتحسين تدفق المعلومات.

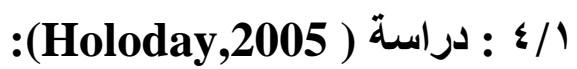

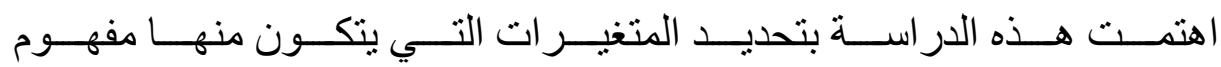

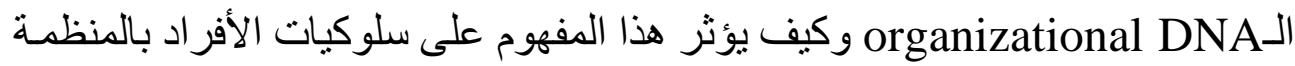
حيث طبقت هذه الدر اسة على . . . ب مشرف في مجال الصناعات التحويلية ، لوضـع القو اعد الخاصة بالعمل وتوصلت الدر اسة إلى مجمو عة من النتائج نذكر منها:

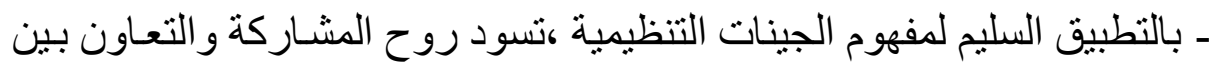

$$
\text { العاملين ويميلون إلى الأداء الجماعي. }
$$

- بالتطبيق السليم لمفهوم الجينـات التنظيميـة ، تزداد قدرة الأفر اد العـاملين على

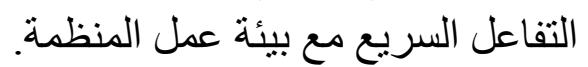

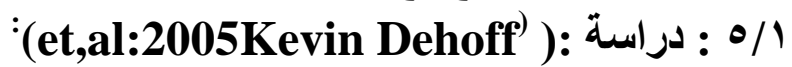

تتاول الباحثون أثر الجينات التتظيمية متمثلة في أبعادها الأربعة (حقوق اتخاذ

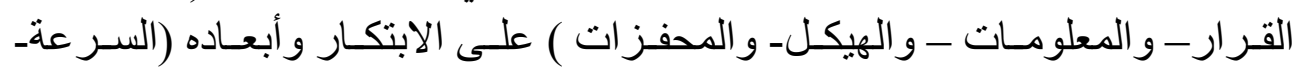

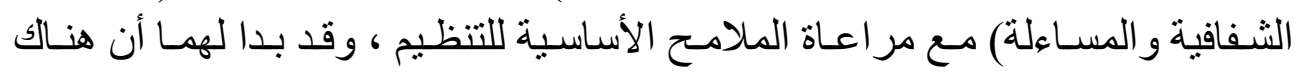




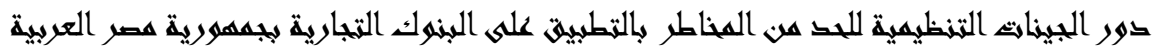
لمياء عيد عطا ابراهميه

منظمـات صـحية وأخرى غيـر صـحية فالمنظمـة الصـحية هي التـي تتسـم بالمرونـة و الإنتـاج في المو عد بالضـبط كالمنظمـة العسكرية، أمـا المنظمـة غيـر الصـحية فهي المنظمـة التي تتسـم بالإنتـاج بكميـات كبيـرة وحجم المنظمـة كبير ،كمـا أن المنظدـات الصحية هي التي تنتهج السر عة و الثفافية و المساءلة.

و انتهت الدر اسة إلى أن كبار المسئولين بالمنظهـة غير الصـحية يقضـون وقتا

طويلا في صـر اع مـع مشـاكل المنظمهة وليس بنـاء المنظمـة، و المشكلة الأساسية أن

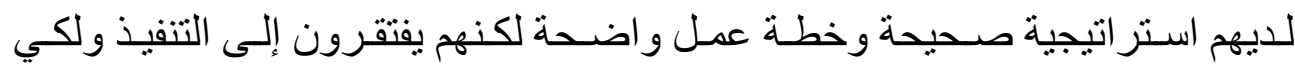
تستطيع المنظمة التغيير فعليها بتجديد الجينات التتظيمية ولن يحدث ذلك إلا من خلال: لكي تنجح في التغيير بجب أن تبدأ بالقيادة العليا في المنظمة .

تجهيز الصف الثاني من الإدارة الوسطى وحثـدهم ليكونـوا متعصبين لعمليـة التغيير ويتعين على الإدارة العليا تمكين هؤلاء من سلطة اتخاذ القرار.

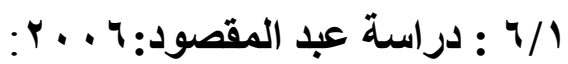

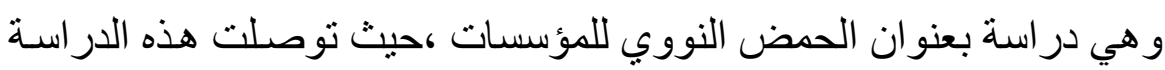
إلـى أن التطبيـق السـليم لمفهـوم Organizational DNA تزيـد مـن قـدرة الأفـر اد العـاملين على التفاعل السـريع مـع بيئة عمل المنظمـة مدـا بسـاعد على ارتفـاع الأداء وزيادة دافع الإنجاز.

و أكدث هـذه الدر اسـة على أن الحمـض النــوري لأي منظمـة بتكـون مسن أربعـة عناصر هي (حقوق اتخاذ القرار ،و المعلومات ،و المحفز ات ،و الهيكل التنظيمي )،هذه

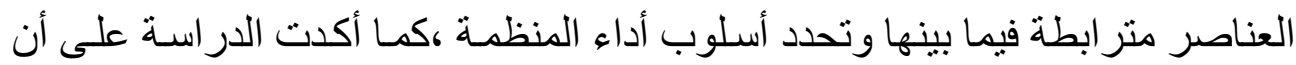
التقصير في عنصـر واحد من هذه العناصـر من شـأنه أن بيؤثر في العناصـر الثلاثة الأخرى بأثكال غير مقصودة، مما قد بؤثر سلبا على أداء المنظمة بدلا من دفعها إلى الأمام.

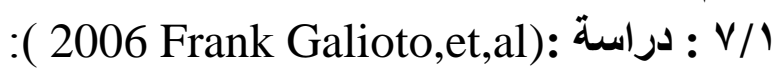

اتجهر الدراسة إلى المنظمة من منظور الميزة التنافسية التي تحملها في مصفوفتها (القالب)(Matrix) و أن هذه المبزة هي مفتاح المصفوفة الحقيقي ، و أنه لم يعد من اللائق للمنظمات في ظل ظروف المنافسة العالمية أن تُعالج العلامة التجارية ، و الفئة وجغر افيا المنظمة، بل عليها أن تبحث تنظيميا في أمرين : أـ بذل المزيد من نقل الخطوط و المربعات باللهيكل التتظيمي ،ودمج وتوحيد حقوق 


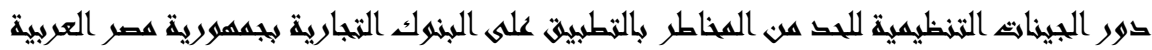
لمياء عيد عطا ابراهميه

$$
\text { اتخاذ القرار، و المحفز ات ،وتدفق المعلومات . }
$$

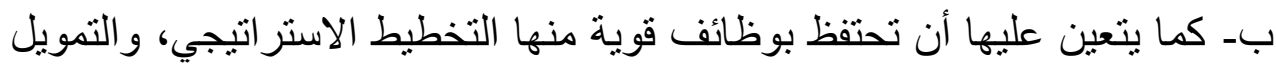
و التسويق ،و المر اقبة و التنسيق وضبط تونة بونه المؤسسة ككل.

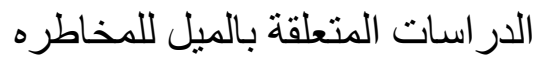

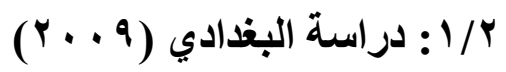

در اسة بعنوان" قياس الفروق بين اتجاهات قيادات البنوك التقليدية و الاسلامية السعودية نحو المخاطرة "استهدفت الدراسة قياس درجة تقبل المخاطر لدي مجمو عة لته

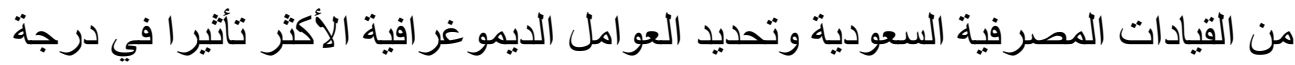

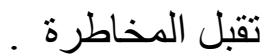

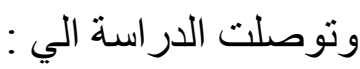

ا ـ درجة تقبل المخاطر لاي المديرين محل الدر اسة سواء بالنسبة لإجمالي مفردات العينة. r- وجود ارتباط ضعيف سالب بين معظم العوامل الديمو غر افية المختارة من الدر اسة ץ- وجود اختلاف بين افر اد العينة محل الدراسة في درجة تقبلهم للمخاطرة تبعا

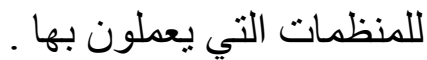

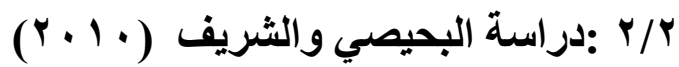
بعنوان " مخاطر نظم المعلومات المحاسبية الالكترونية : در اسة تطبيقية على البنوك العاملة

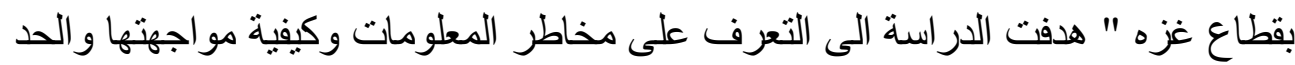
من آثرها ـ وقد توصلت الدراسة من خلال شقها التطبيقي الى عدم حدوث هذه المخاطر بثكل متكرر ، وأرجعت سبب حدوث هذه المخاطر الى قلة الخبرة و التدريب لدى موظفي

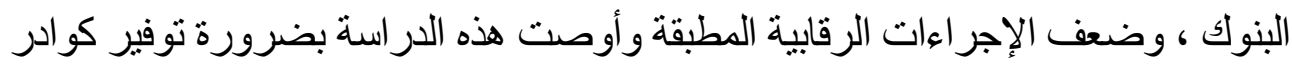

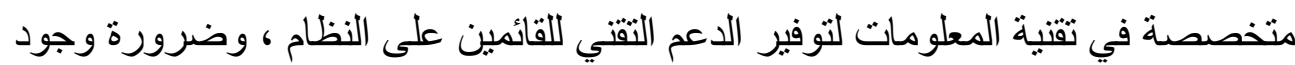

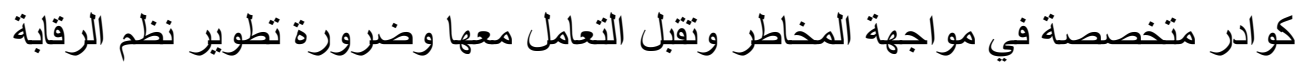

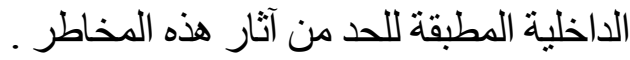
Muhrala\&Ogundeji,2013) ,Computerized Accounting Information Systems and Perceived Security threats in Developing Economies : The 


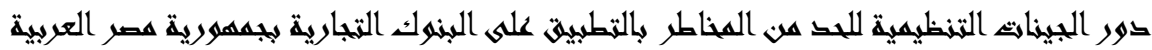
لمياء عيد عطا ابراهميه

Nigerian Case"

هدفت الدراسة الى تقصى آراء عينة الدراسة حول مدى حدوث المخاطر و التهيدات التي تواجه نظم المعلومات المحاسبية الاكترونية ، وأي من هذه المخاطر الأكثر حدوثاً

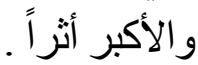

توصلت الدراسة الى أهم مخاطر تواجه النظم الالكترونية في المنشآت النيجيرية

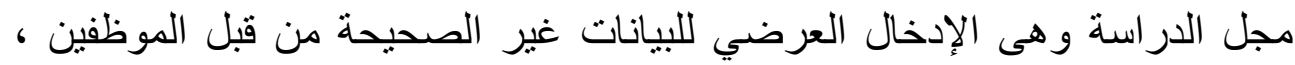

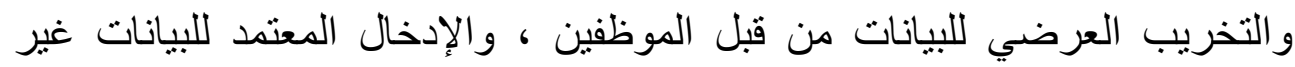

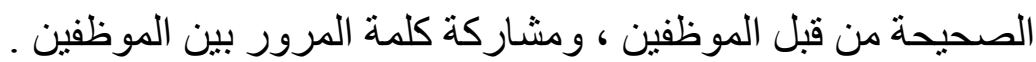

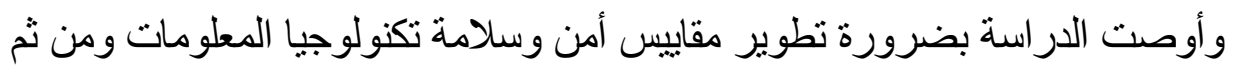

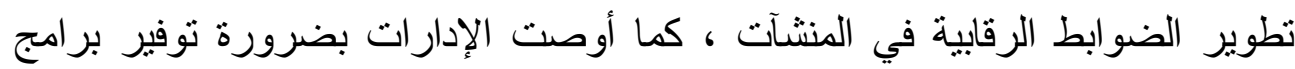
تدرييية للعاملين بالمنشأة حول أمن وسلامة المعلومات ، وألثات الثنارت إلى أهمية نوفير نظم مر اقبة وتقيبيم مستمرة.

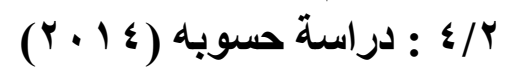

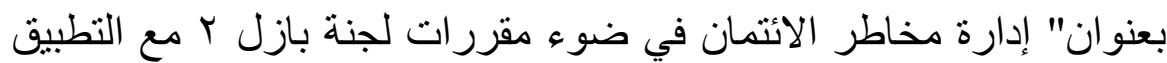

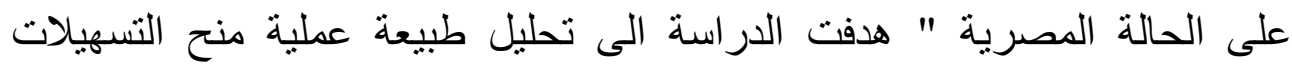

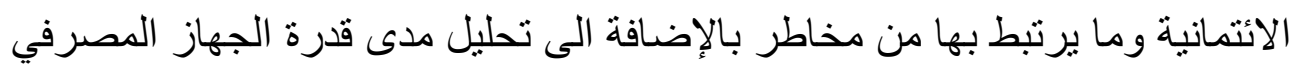

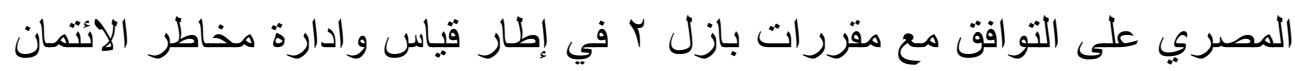
وما يرتبط بذللك من توفر لدقومات التطبيق فضلا عن نوفر البيئة السليمة للرقابة الترانة

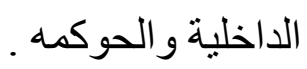

وأوصت الدراسة بضرورة تطبيق اتفاقية بازل r في ادارة مخاطر الايتمان

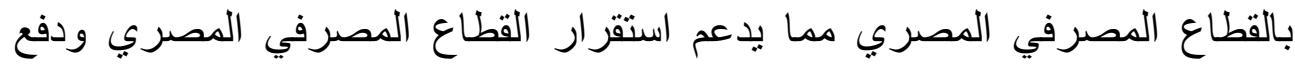

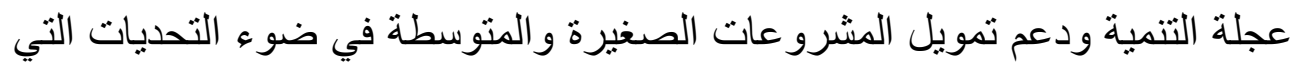

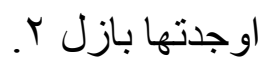
بوان

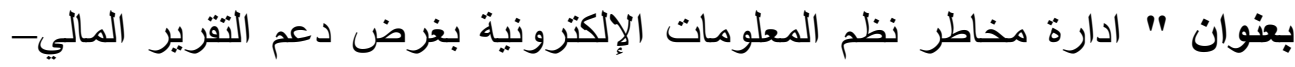

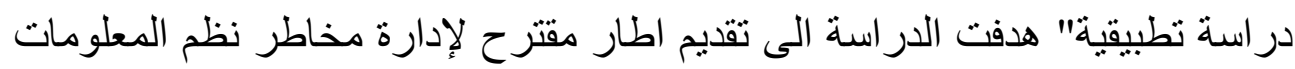

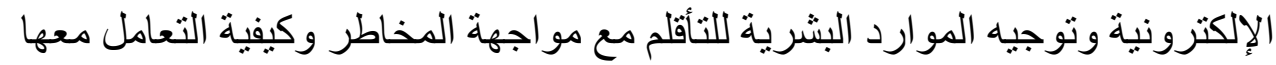

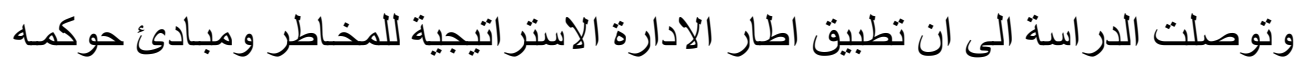




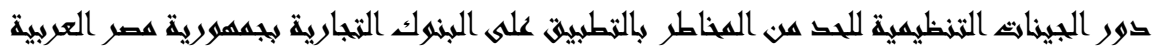
لمياء عيد عطا ابراهميه

تكنولوجيـا المعلومـات تأثثراً ايجابيـاً على إدارة مخـاطر نظم المعلومـات الالكترونيـة وبالتالي تخفيض المخـاطر و التهديدات التي تقوض فرص الحصـول على معلومـات مانئمة و مان.

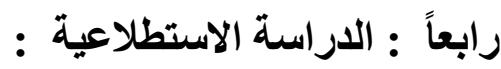
يمكن القيام بالدر اسة الاستطلاعية على مر حلتين و هما على النحو التالي : ا ـ الدر استة المكتبية:

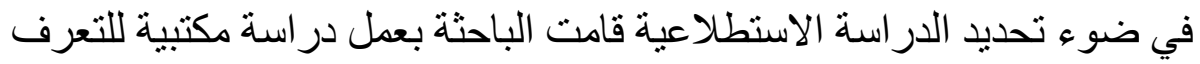
على متغيرات الدر اسة ، وذللك من خلال الرجوع إلى كافة المصادر ذات العلاقة بموضوع الدراسة ، وشملت هذه المصادر المراجع العربية والأجنبية من كتب ودوريات وتقارير علمية ذات علاقة بالمتغير ات ، بالإضافة إلى استخدام مواقع البحث: الإلكتروني للتعرف على الإحصائيات ذات العلاقة بمجال التطبيق وكذللك المساهمة في بناء الإطار النظري للإر استة . لإسي أسفرت الدراسة المكتبية أن الجينات التنظيمية تساهم في العديد من المتغيرات التسويقية مثل تحقيق الميزة التنافسية ، بالإضافة إلى التأثثر على معدلات نمو الثركات في سوق العمل ، كما أن الجينات التظظيمية تؤثز على كافة المستويات الإدارية بالمنظمة ، الأمر الذي ينعكس على الصورة الذهنية للمنظمة ككل مما بساهم ذلك في تحقيق نجاح على المدى البعيد ، ولذا فالمنظمات الناجحة هي تلاك المنظمات التي تقوم بحسن استغلال الحمض النووي لديها وذلك لأنه ينعكس على قدرات العاملين في التفاعل مع بيئة العمل داخل محيط العمل مما يساعد على ارتفاع الأداء

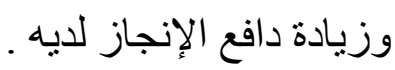

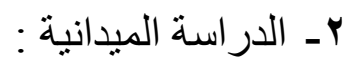

تعتبر البنوك التجارية المصرية أحد أهم القطاعات الرئيسية التي تلعب دوراً كبير ا في تحقيق التنمية الاقتصادية والاجتماعي للمجتمع المصري ، فهي تسهم في تمويل المثاريع الاسثثمارية و إشباع الحاجات المتعددة للعملاء سواء أفراد أو مؤسسات ، فئهي كما تساهم في توسيع حجم السوق من خلال تيسير وتنشيط المعاملات المالية و التجارية ، كما أن البنوك التجارية العامة في مصر تضم شريحة كبيرة من العاملين ، ويتضح ذللك كما يلي : 


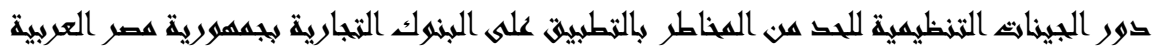
لمياء عيد عطا ابراهميه

جدول رقم ( 1 ) عدد العاملين بالبنوك العامة التجارية بمحافظة الدقهلية

\begin{tabular}{|c|c|c|}
\hline عدد العاملين & عدد الفروع & اسم البنك \\
\hline$r \ldots$ & 14 & البنك الأهلي المصري \\
\hline rr. & 17 & بنك مصر \\
\hline$r \varepsilon$. & 11 & بنك القاهرة \\
\hline 17. & $\varepsilon$. & المجموع \\
\hline
\end{tabular}

المصدر : إعداد الباحث في ضوع النشرة الاحصائية الصادرة عن البنوك المصرية .

جدول رقم (r ) عدد العاملين بالبنوك الخاصة التجارية بمحافظة الدقهلية

\begin{tabular}{|c|c|c|}
\hline عدد العاملين & عدد الفروع & اسم البنكأك \\
\hline r). & V & بنك الاسكندرية \\
\hline 00 & $\varepsilon$ & المصرف المتحد \\
\hline 0. & $\varepsilon$ & البنك التجاري الدولي \\
\hline$\varepsilon \varepsilon$ & 0 & كريدي اجريكول \\
\hline r & $r$ & البنلك القطري \\
\hline ro & $\varepsilon$ & بنك أبو ظبي الوطني \\
\hline r. & 7 & البنك العربي الإفريقي \\
\hline ro & $\varepsilon$ & البنلك المصري \\
\hline$r \cdot$ & r & بنك بن HSBC \\
\hline r & r & البنك الوطني المصري \\
\hline ro & 0 & البنك الأهلي المتحد \\
\hline 00. & $\varepsilon V$ & المجموع \\
\hline $1 \leq 1$. & $\Lambda V$ & إجمالي عدد البنوك \\
\hline
\end{tabular}

المصدر : إعداد الباحث في ضوء النشرة الاحصائية الصادرة عن البنوك المصرية المصدية . 


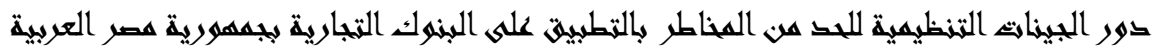
لمياء عيد عطا ابراهميه

كما أن البنوك التجارية تساهم في الاقتصاد القومي ، وذلك من خلال عمليات الإقر اض التي تمنحها للقطاعات المختلفة جدول رقم (ب) مقابلاث الدراسة الاستطلاعية

\begin{tabular}{|c|c|c|c|c|}
\hline الغرض من المقابلة & تاريخ المقابلة & البنك & العدد & الوظيفة \\
\hline \multirow{5}{*}{ 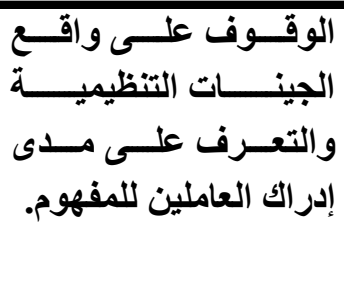 } & \multirow{5}{*}{$r \cdot \mid \varepsilon / / r / 10$} & \multirow{5}{*}{ البنك الأهلي } & 1 & المدير \\
\hline & & & 1 & نائب المدير \\
\hline & & & 1 & مدير التسويق \\
\hline & & & $\varepsilon$ & رؤساء الأققسام \\
\hline & & & 0 & عاملين بالبنك \\
\hline \multirow{6}{*}{ 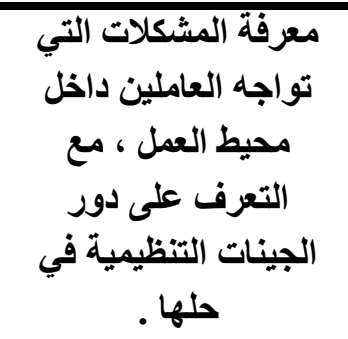 } & \multirow{6}{*}{$r \cdot \mid \leq / 1 \cdot r}$. & \multirow{6}{*}{ بنك مصر } & 1 & المدير \\
\hline & & & 1 & نائب المدير \\
\hline & & & $r$ & مديرين إدارة \\
\hline & & & $\varepsilon$ & رؤسساء أقسام \\
\hline & & & 0 & عاملين \\
\hline & & & & \\
\hline \multirow{7}{*}{ 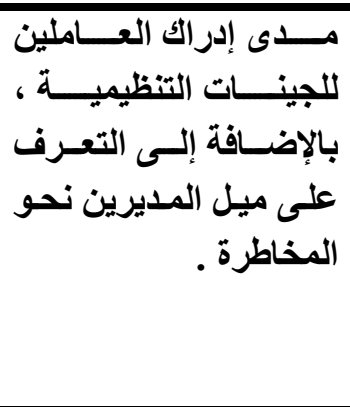 } & \multirow{7}{*}{$r .1 \leq / 1 / 1 r$} & \multirow{7}{*}{ بنك الاسكندرية } & 1 & المدير \\
\hline & & & 1 & نائب المدير \\
\hline & & & 1 & مدير التسويق \\
\hline & & & 1 & مدير إدارة \\
\hline & & & & العاملين \\
\hline & & & 0 & رؤساء الأققسام \\
\hline & & & 0 & عاملين \\
\hline \multirow{7}{*}{ 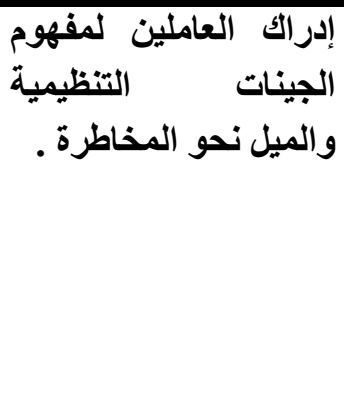 } & \multirow{7}{*}{$r .1 \leq / 11 / 17$} & \multirow{7}{*}{ البنك التجاري } & 1 & المدير \\
\hline & & & 1 & نائب المدير \\
\hline & & & 1 & مدير التسويق \\
\hline & & & 1 & مدير إدارة \\
\hline & & & & العاملين \\
\hline & & & 0 & رؤساء الأقتسام \\
\hline & & & 11 & عاملين \\
\hline & & & 7. & المجموع \\
\hline
\end{tabular}

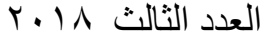
المجلد التاسع 


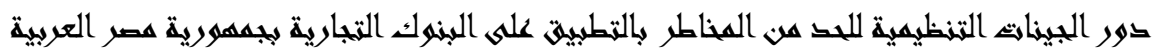
لمياء عيد عطا ابراهميه

\section{أسفرت نتائج الدراسة الاستطلاعية عن النتائج التالية :}

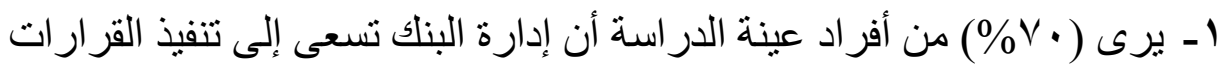
الاستر اتيجية ، بينما يرى ( • م\% ) من عينة الدراسة أنه لا يوجد سر عة في تنفيذ القرار ات الاستر اتيجية المتعلقة بالبنك و هذا بعد بطبيعة الحال مؤشر جيد عن رغبة البنوك التجارية محل الدراسة عن تفعيل السرعة في اتخاذ القرار ات التي تخدم مصلحة البنك ، ويتضح ذلك من الثكل التالي :

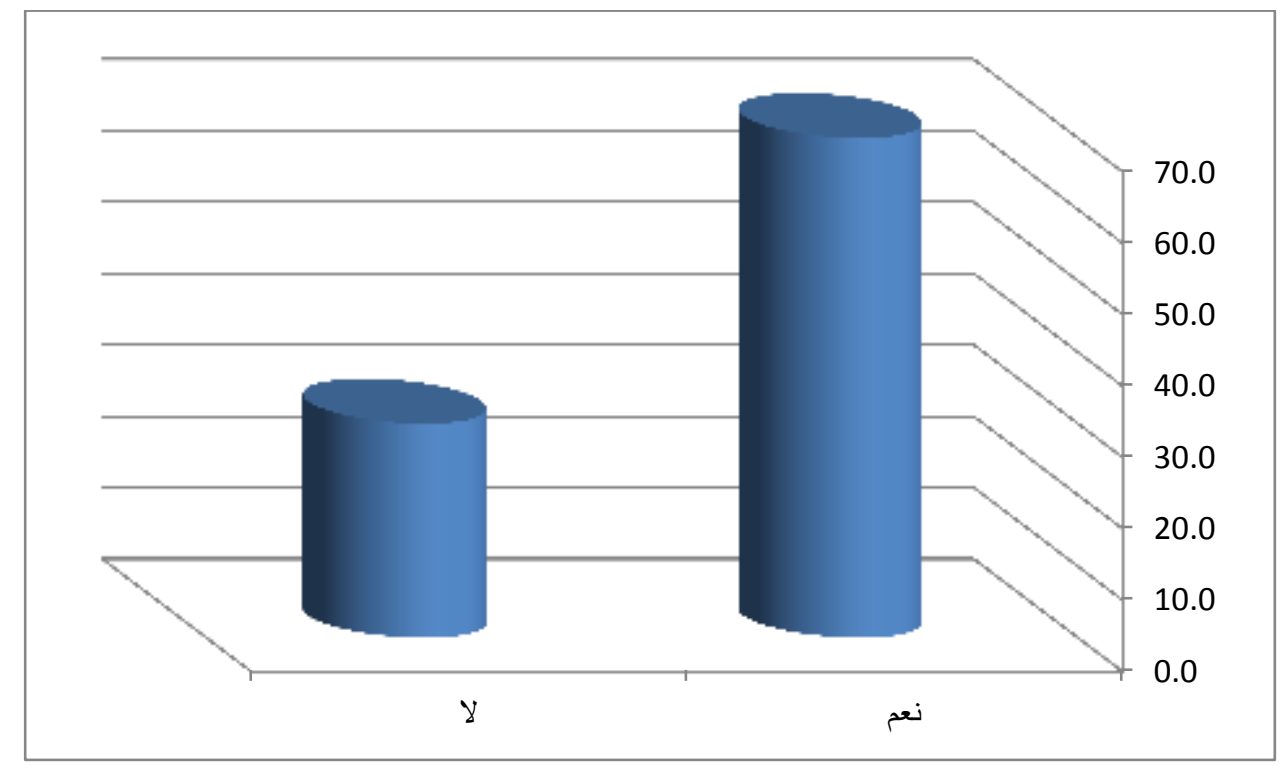

شكل رقم (1) نتيجة الدراسة الاستطلاعية حول

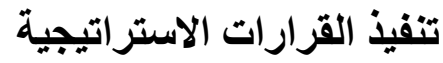

المصدر : إعداد الباحثة في ضوء النتائج الاحصائية

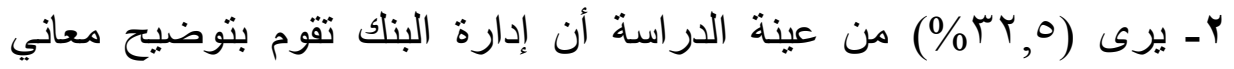
الجنيات التنظيمية وتقوم بعمل دورات تدريبية للعاملين توضح لهم ماهية

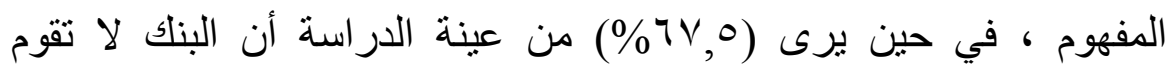
بتوضيح معاني الجنيات التنظيمية وتقوم بعمل دورات تدريبية للعاملين توضتح لهم ماهية المفهوم ، مما يدل على ضرورة تعزيز مفهوم الجنيات التظظيمية و الميل نحو المخاطرة وتأثير هما على القرارات داخل البنك

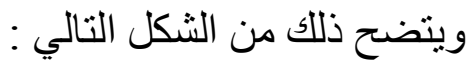




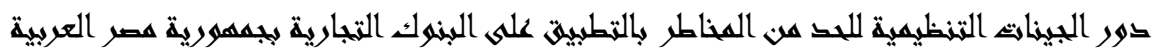
لمياء عيد عطا ابراهيمي

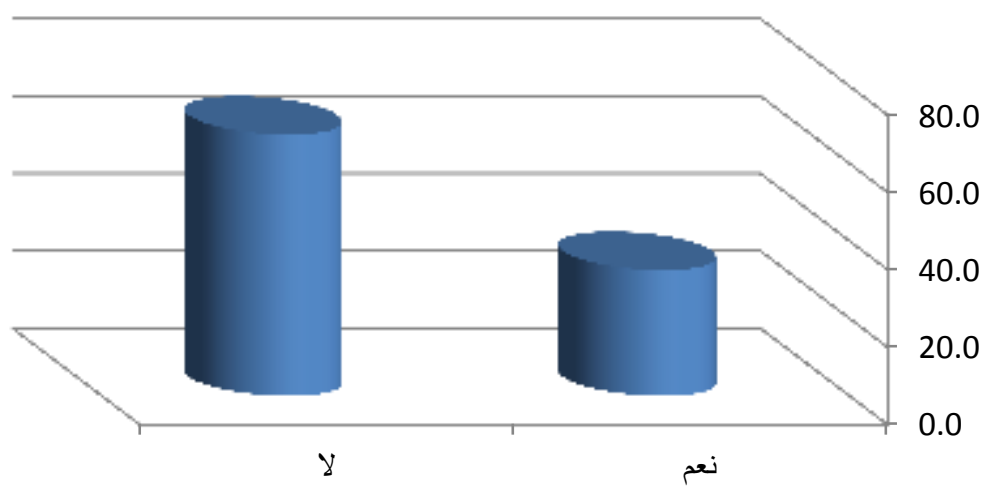

\section{شكل رقم (r) توضيح مفهوم الجينات التنظيمية}

المصدر : إعداد الباحثة في ضوء النتائج الاحصائية

r- يرى ( •r\%) من أفر اد عينة الدراسة أن العملاء يعتقدون أنهيوجد في البنك

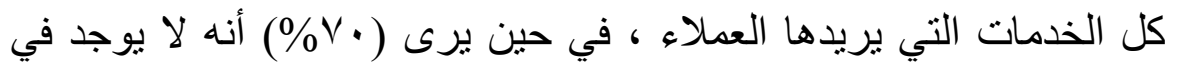
البنك كل الخدمات التي يريدها العمالاء ، ويتضح ذلك من خلال الثكل التالي:

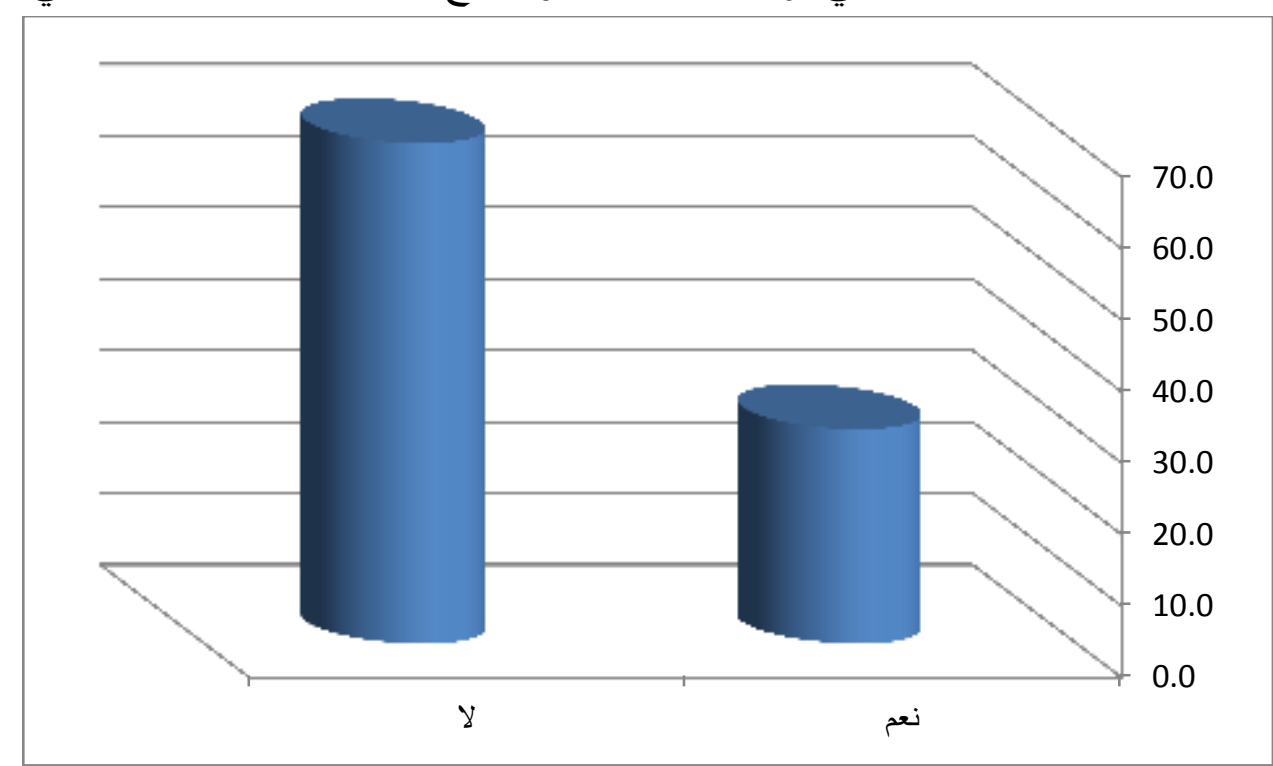

شكل رقم (ب) نتيجة الار اسة الاستطلاعية حول توفير الخدمات للعملاء

المصدر : إعداد الباحثة في ضوء النتائج الاحصائية . 


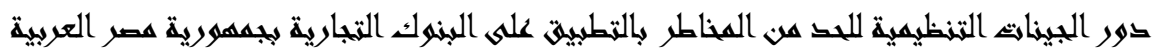
لمياء عيد عطا ابراهميه

خامساً: مشكلة الدر اسة

يمكن بلورة مشكلة الدر اسة في التساؤلات التالية :

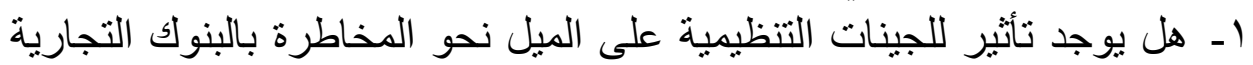

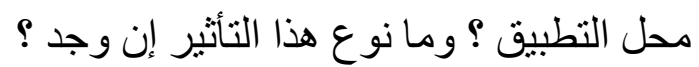

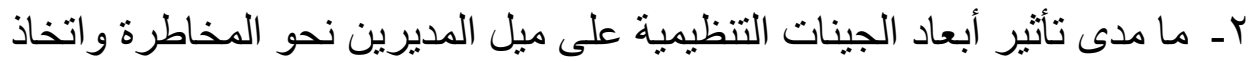

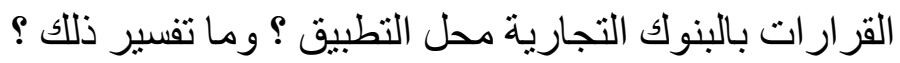

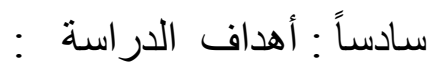

تسعى الدراسة الحالية إلى تحقيق مجمو عة من الأهداف و هي على النحو التالي : ا - التعرف على مدى وجود تأثير للجينات التنظيمية على الميل نحو المخاطرة

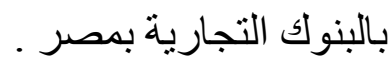

بـ توضيح تأثنر أبعاد الجينات التنظيمية على ميل المديرين نحو المخاطرة و اتخاذ

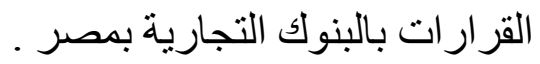

سابعاً: فروض الدراسة : تسعى هذه الدر اسة في ضوء أهدفها إلى اختبار مدى صحة الفروض التالي: الفرض الأول : لا يوجد ارتباط معنوي بين الجينات التنظيمية و الحد من المخاطرة . الفرض الثاني :لا يوجد تأثنير معنوي لأبعاد الجينات التتظيمية والحد من المخاطر

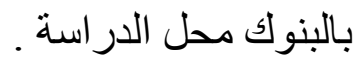

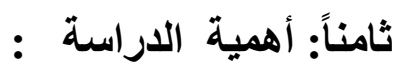

تسـتمد هـذه الدر اسـة أهميتهـا مـن خـلال الـربط بـين الجينـات التنظيميـة بأبعادهـا

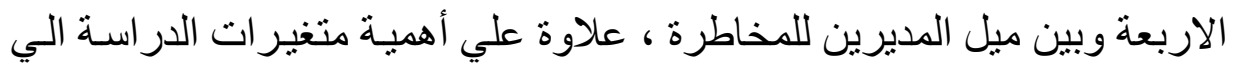

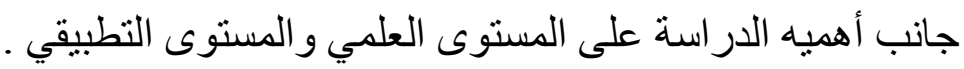

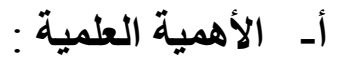

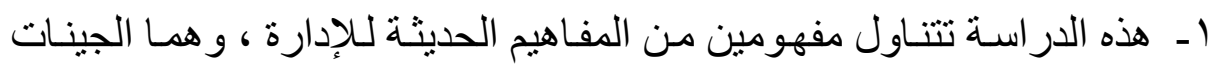

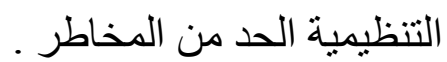




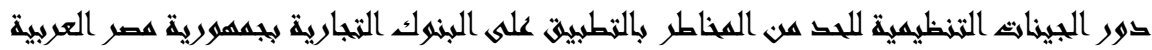
لمياء عيط عطا ابراهيمر

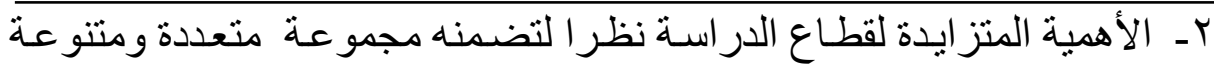

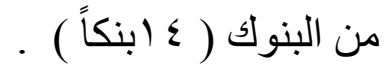

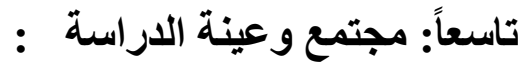

يتمثل مجتمع الدراسة في جميع العاملين بالبنوك التجارية محل التطبيق ، وقد بلغ عددهم وفقا للنشرات الإحصائية الصادرة عن البنك المركزي ( (1 ()) ، ويمكن توضيح مجتمع الدر اسة و النسبة المتعلقة بكل مجتمع ، كما في الجدول التالي :

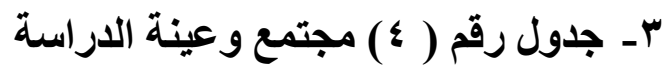

\begin{tabular}{|c|c|c|}
\hline العينة & المجثمع & اسم البنك \\
\hline 70 & r.. & البنك الأهلي المصري \\
\hline 79 & rr. & بنلك مصر \\
\hline Or & $r \varepsilon$. & بنلك القاهرة \\
\hline$\varepsilon 7$ & rl. & بنك الاسكندرية \\
\hline 14 & 00 & المصرف المتحد \\
\hline 11 & 0. & البنك التجار \\
\hline 9 & $\varepsilon \varepsilon$ & كريدي اجر \\
\hline V & 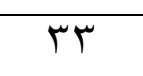 & البنك الا \\
\hline$V$ & ס & بنلك أبو ظبي الوطني \\
\hline 7 & r. & البنك العربي الإفريقي \\
\hline 0 & ro & البنك المصري الخليجي \\
\hline$\varepsilon$ & $r$ & بنك HSBC \\
\hline$\varepsilon$ & rr & البنك الوطني المصري \\
\hline 0 & ro & البنك الأهلي المتحد \\
\hline$r \cdot r$ & $\mid \varepsilon 1$ & In \\
\hline
\end{tabular}

المصدر : إعداد الباحث في ضوء النشرة الاحصائية الصادرة عن البنوك المصرية . عاشراً: أسلوب : الأدراسة : يتمثل أسلوب الدر اسة في الآتي :

ـ - البيانات الثاتوية: وتتمثل في الكتب و البحوث و الدر اسـات العلميـة العربيـة و الأجنبيـة و النشـر ات و التقارير ومواقـع الإنترنـت ،في مجـال الجينـات 


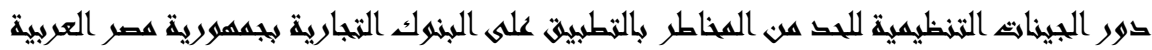
لمياء عيد عطا ابراهميه

التتظيميـة وميـل المـديرين للمخـاطرة . وكذللك الدر اسـات الســابقة التـي

تعرضث لهذه البنوك التجارية العامة و الخاصة بجمهورية مصر العربية . rـ البيانـات الأوليةة: تتمثل هذه البيانـات في البيانـات التي قامـت الباحثة في

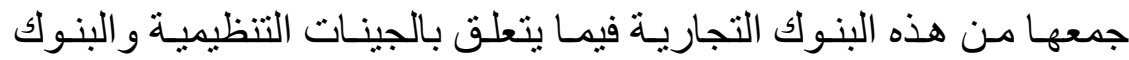
التجارية ،و من أجل ذلك سوف قامت الباحثة بعمل در اسة مبدانية .

الحادي عشر : حدود الاراسة : الجنة : أ. أ. حدود تطبيقية

تقتصر الدراسة التطبيقية علي البنوك التجارية العامة والخاصة بمحافظة الدقهلية وذللك نظر ا لمحل اقامة الباحثة وموقع عملها ومراعاة البعد الجغرافي بحيث تخدم نتائج الدر اسة البيئة المحيطة ، وسهولة تجميع البيانات ومر اعاة عامل الوقت وته .

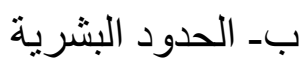

تقتصر الدر اسة على العاملين بالبنوك التجارية العامة و الخاصة بمحافظه الدقهلية . ج- الحدود الزمانية :

قامت الباحثة بتجميع البيانات المبدانية خلال النصف الثاني من عام 7 ا ـ ب م . د- الحدود المكانية : تقتصر هذه الدراسة علي البنوك التجارية العامة والخاصة بجمهورية مصر

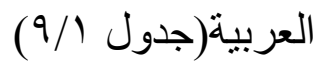
الثاني عشر: أساليب التحليل الإحصائي : اعتمـدت الباحثـة في تحليـل بيانـات الدر اسـة على أسـلوب تحليـل المســار (Analysis Of Moment Structures)AMOS باستخدام الأداة التحليلية

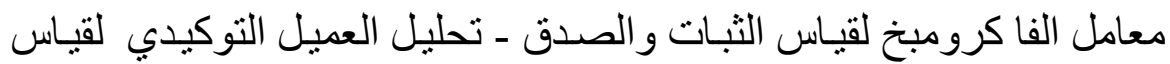

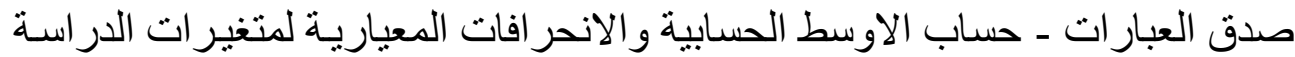

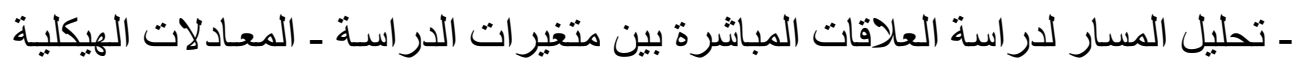

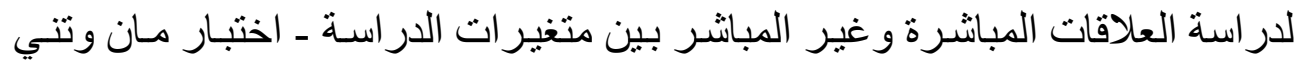

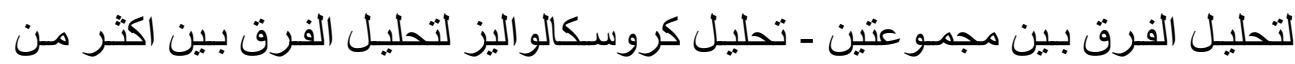
مجمو عتين 


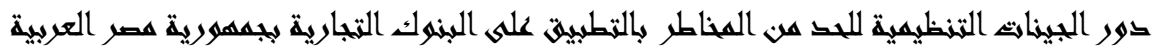
لمياء عيد عطا ابراهميه

الانتخائجج :

يمكن للباحثة توضيح النتائج و التوصبات المتعلقة بالدر اسة الحالبة من خلال مجمو عـة من العناصر وهي على النحو التالي :

(1)وجود علاقة معنوية لمعظم المتغيرات الممثلة لحقوق اتخاذ القرار ات علي عملية اتخاذ القرار ات الادارية ( تخطيط - تنظيم - توجيه - رقابة ) وازداد هذا

التأثير مع دخول المتغير الوسيط وهو ميل المديرين للمخاطرة .

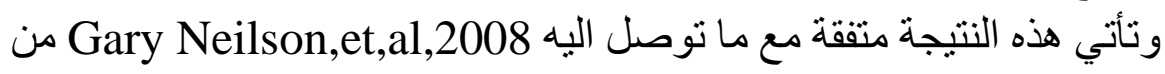
نتائج وذللك بالنسبة لوجود فروق معنوية بين الثركات ا فيما يتعلق بحقوق اتخاذ القرار

(Y) (Yنالك مجمو عة من العناصر تساهم في تكوين قدرة الهيكل التنظيمي علي مبل المديرين للمخاطرة و أثر ذلك علي قر ار اتهم .

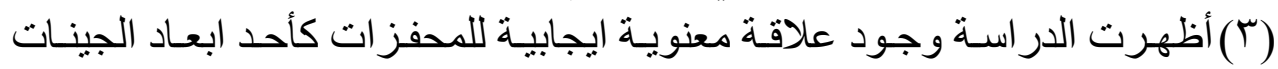
التنظيمية علي القر ار ات الادارية وتزداد بتدخل ميل المديرين للمخاطرة . ( ) هنالك مجمو عة من العناصر الخاصة بالمعلومات تزيد من قدرة المدير على اتخاذ

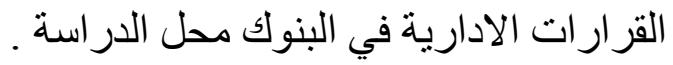

(0) أوضحت الدر اسة أنه علي الرغم من أن القرارات الادارية في ظل مبل المديرين للمخاطرة تتأثر بمجمو عة من محددات الجينات التنظيمية إلا أن هذه المحددات قد تختلف في ترتيب تأثنير ها علي القرار ات الادارية ، فقد جـاء الدو افع و الالتز امـات في المقام الاول ، يليه جودة المعلومات ثم الهيكل التنظيمي . وقد اختلفت الدر اسة مع در اسة لبده حيث اثثتت اختلاف الترتيب فقد جـاء التيكل التنظيمي في المقام الاول يليه المحفز ات ثم المعلومات . (7) بينـت الدر اسـة أن قـرار ات التنظيم أكثر القـرار ات التي تتأثر بمجمو عـة ابعـاد الجينـات التظظيميـة (الهيكل التظظيمي - المعلومـات ـ حقوق اتخـاذ القر ارات المحفز ات ) وتثفق هذه الدر اسة مع در اسـة الساعدي . . 


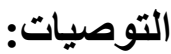

في ضوء الاطار النظري للبحث وبناء علي نتائج التحليل الإحصائي للبيانات الميدانية فانه يمكن صياغة و عرض بعض التوضيات المقترحة و التي قد تساهم في زيادة فعالية

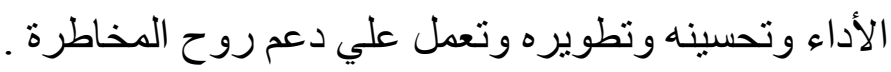

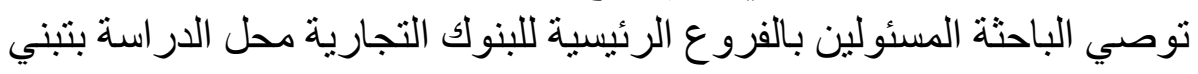

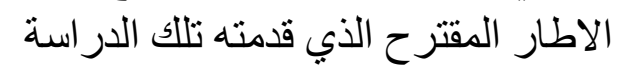

توصي الباحثة بضرورة الاهتمام بالمديرين الثباب و الذين لايهم ميل للمخاطرة

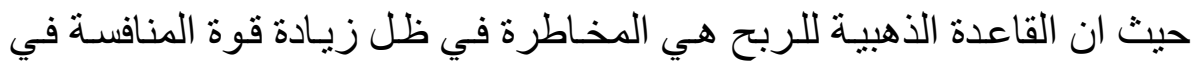

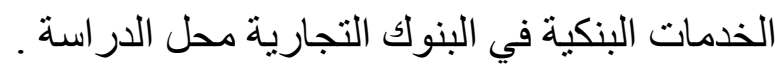

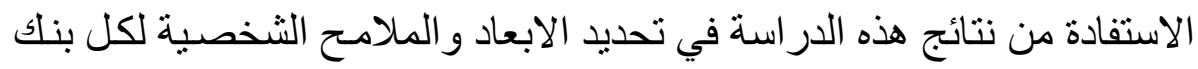

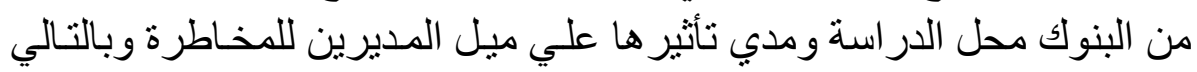

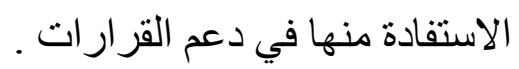

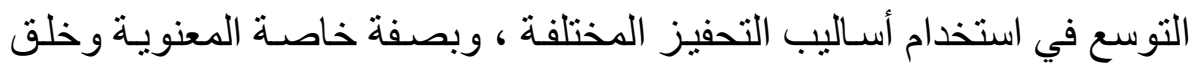

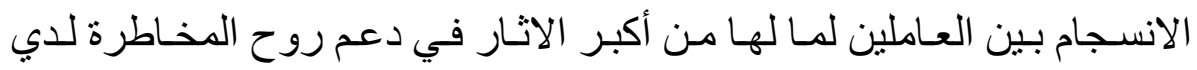

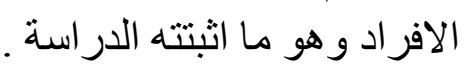
زيادة الاهتمام بالتدريب و التهيئة للمديرين في البنوك محل الدر اسة في بيئة بها

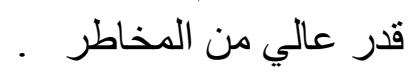

الاعتماد على التدوير الوظيفي أي يلعب المدير دور مدير الائتمان مرة ومرة أخري

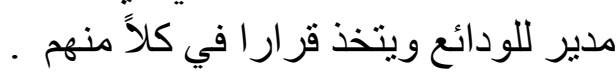




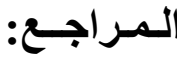

ـ البغدادي ، محمد عبد الحافظ ، 9 . . ب ، قياس الفروق بين اتجاهات قيادات البنولك التقليدية و الاسلامية السعودية نحو المخاطرة ، المجلة المصرية للدراسات التجارية ، كلية التجارة ،

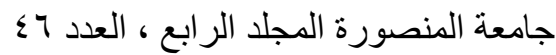

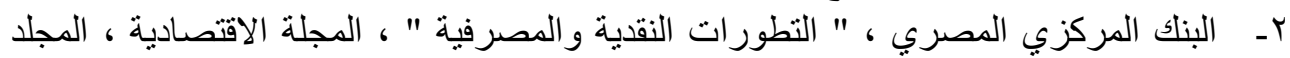

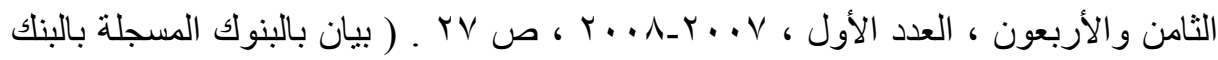

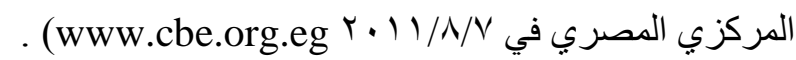

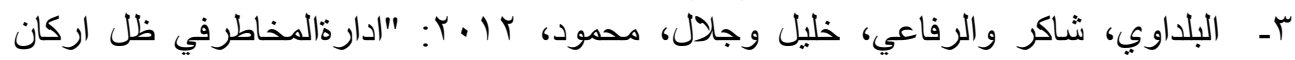

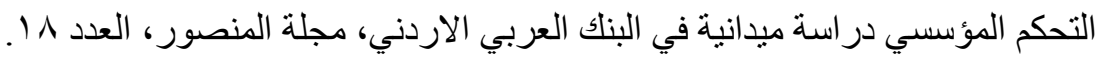

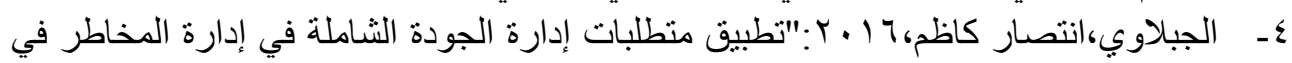

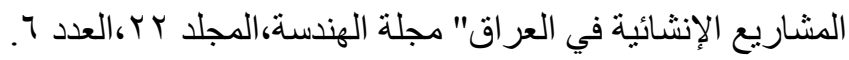

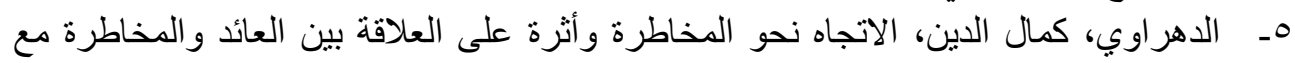

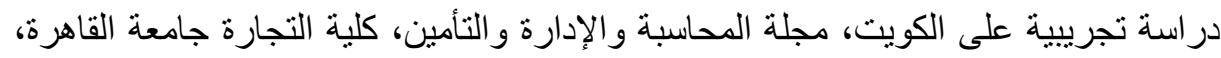

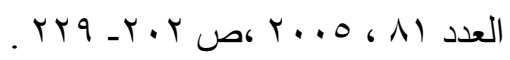

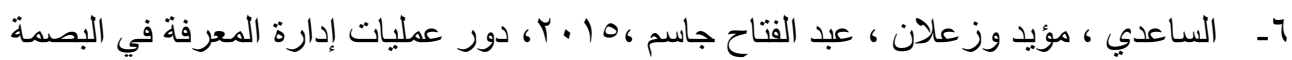
الور اثية التظظيمية DNA لمنظمات الأعمال في عينة من المصارف العيد العر اقية ، مجلة الإدارة و الاقتصاد ، المجلد الثالث ، العدد العاشر . التهن

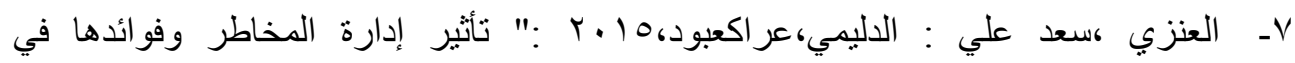

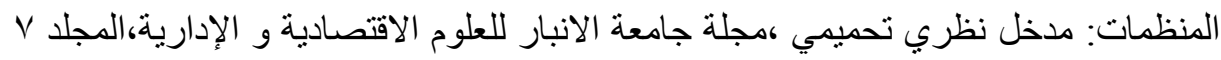

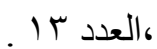

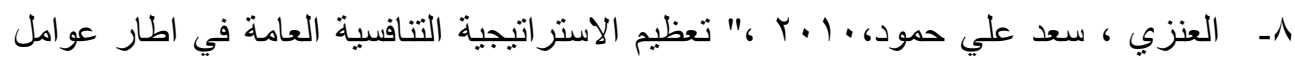

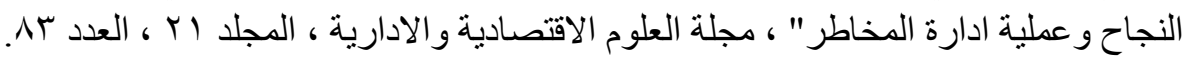

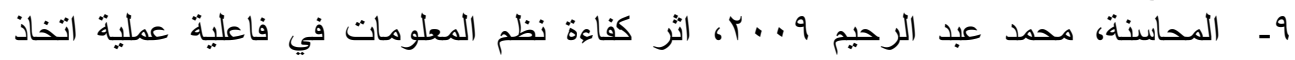

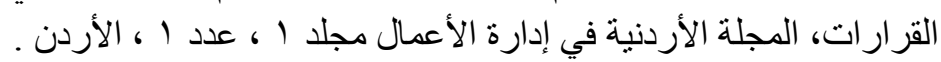

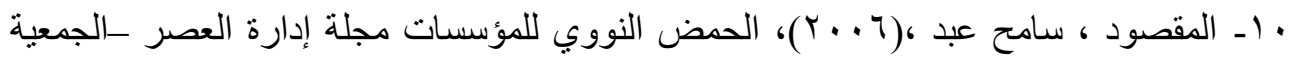
العربية للإدارة ،العدد السادس.

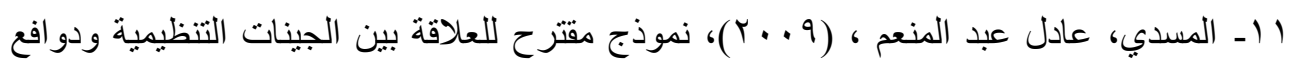

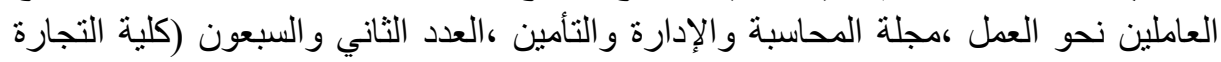
كجامعة القاهرة).

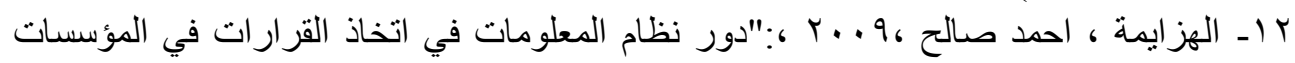

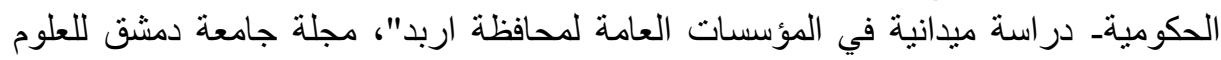

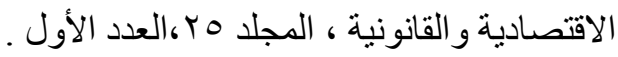

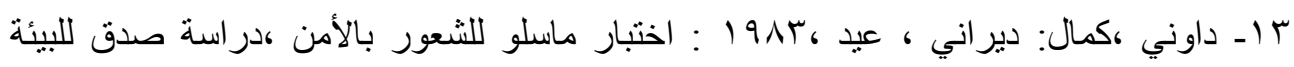

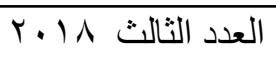
المجلد التاسع 


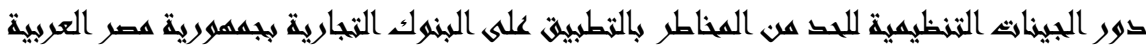
لمياء عيد عطا ابراهميه

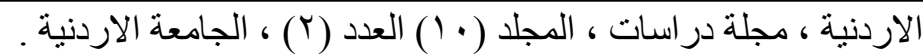

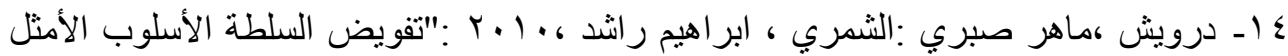

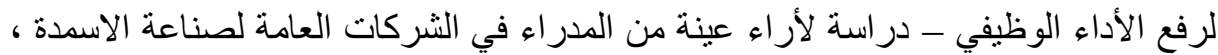

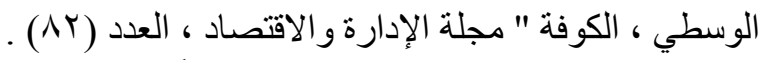

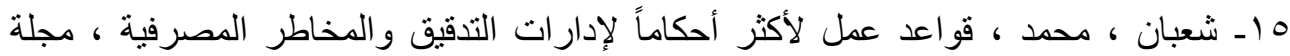

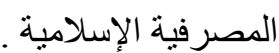

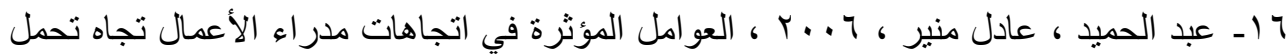

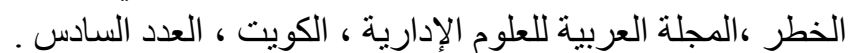

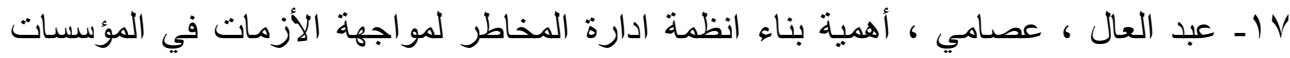

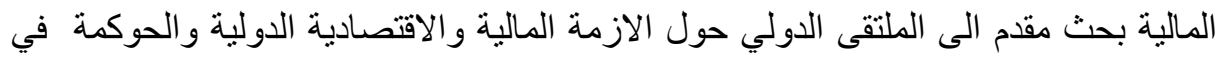

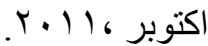

الرسيائل العلمية : الرئر

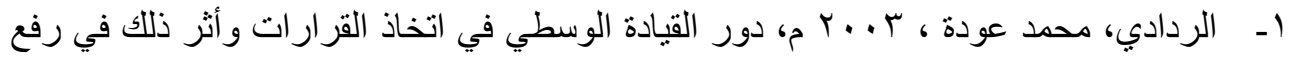
كفاءة الأجهزة الأمنية، رسالة ماجستير غير منشورة، أكاديمية نايف العربية للعلوم الأمنية بالرياض.

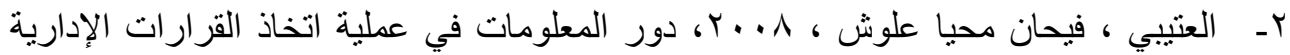

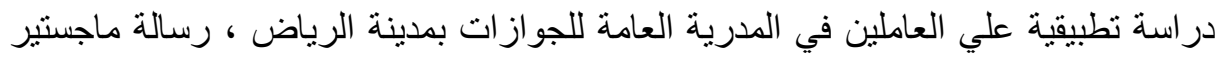

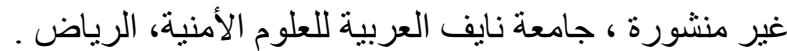

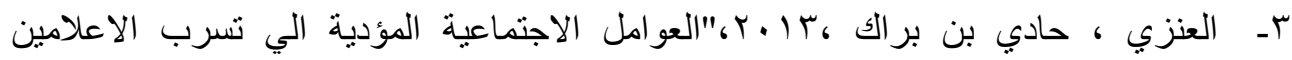
السعوديين في الصحف " ، رسالة ،ماجستير ،جامعة الإمام محمد بن سعود الإسلامية . 


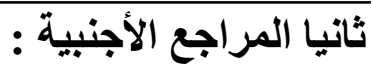

\section{A)Periodicals :-}

1. Barnes,John F.2008:"High performance Organizations:programming Organizational DNA for Success", Southwest Foundation for Biomedical Research".

2. Bossidy,Larry.,Charan,Ram,2002"Execution:The Discipline of Getting Things Done ",Crown Business".

3. Booz,Allen Hamilton ,2002,"When Everyone Agree But Nothing Changes:Aligning People,Incentives and Knowledge to Overcome Oranizational Inertia",Business Strategy Review,www.Strategybusiness.com.

4. -Blenko ,Marcia W.,et al ,2010 Jun."The Decision-Driven Organization",Harvard Business Review.

5. Cindy Skrzycki , "Risk Takers , U.S.News and WorldReport,Jan,2006 ,PP:60-67

6. -Csaszar,Felipe,2012:"Organizational structure as adeterminant of performance:Evidence from mutual funds",strategic management Journal33(6).

7. David G. Knott \& Gary L. Neilson,(2006), Organizing to execute: It's in the DNA, Ivey Business Journal.

8. Davus,L.E.,1966,October:"Industrial Relations",A Journal of Economy and Society,Volume6,Issu1.

9. Drucker ,Peter F.,1988,Jan :"The coming of the New Organization",Harvard Business Review .

10. Dos,Izzet,2007:"School DNA and Its Transfer",American Journalof HumanEcoiogyVol.2,No.1,UniversityofSutcuImam,Kahramanmaras, Tu rkey

11. Eiii, Hang Shin, and Moon-Gi Sun, (1999), An Analysis of Structural Determinants of Organizational Effectiveness, International Journal of Korean Studies,Vol.3, NO.1, P.P163-189.

12. Fottler,M.D\&Ford,R.C.1995. Empowerment :A matter of degree.Academy of Management Executive,Vol.9,No.3. 


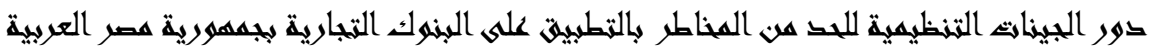
لمياء عيد حما ابراسهيه

13. Flumerfelt,Shannon,2008:"Grounded Theory Research for school/districts on organizational learning and development,OaklandUniversity:pawley Learning Institute.

14. Frank Galioto,et,al, (2006), The Matrix Reloaded: The Multi-Axis Organization as Key to Competitive Advantage, Booz Allen Hamilton.

15. Gharmy,B.(2006),"The Factor of Organizational DNA", Harvard Business, Vol,119, pp:3-10.

16. Gary Neilson, et,al, (2004), The Seven Types Of Organizational DNA, Strategy, Business, Issue 35.

17. Gary Neilson,et,al,(2008), The Secrets to Successful Strategy Execution., Harvard Business Review, Issue.

18. Griffiths - RSM international , Internal Audit and Risk Management, BFSI sector, 6-8 http:// www astute consultin .

19. Owen, Smith Jason,2011,January :"The Institutionalization of expertise in university Licensing ",University of Michigan ,Theory of Society40(1) .

20. - Green Mark .R .Risk and Insurance ,3d Ed U.S.A 1980.

21. Gouilart,FrancisJ.\&Killy James N.,1995:"TransForming the Organization",Publisher:McGraw-Hill,Inc.,ISBN:0-07-0340676.,page323.

22. -Hussain,mohammedGalib\&Thirupathy,A.2012,December :"Employee Motivation :Conceptual Dimensions "Journal of Commerce \&Behavioural Science,Vol.02,Num.02.

23. Ivanoz,Sergey,2013,"Discovering Unused Organizational potential Government,Multinationals,Military http://www.sergeyivanov.org/pages/Corporate DNA.aspx

24. Jaruzelski. B and Kumar. J., "Technology's blinds spot : adaptability", Information Week's Optimize, November, 2004. 